\title{
Injection Mold Unit Design of Combined Spoon-Fork (Spork) Product
}

\author{
Arif Budi Wicaksono*, Muchlis \\ Mechanical Engineering Study Program, Faculty of Industrial Technology, Universitas Islam Indonesia \\ Jalan Kaliurang Km 14.5, Ngemplak, Sleman, Yogyakarta 55584 \\ *Corresponding author: arifbudi_wicaksono@uii.ac.id
}

\begin{abstract}
This research aims to design injection molding unit construction for combined spoon and fork products that are in accordance with industrial standards. The mold unit designed consists of two kinds of layouts, namely grid layout and radial layout, the combined product spoon and fork grid layout that will be used is the LKM AI 4050 moldbase standard and the radial layout spoon and fork combined product will be used is the LKM AI 6065 moldbase standard. The optimum mold construction uses a grid layout and block runner system with dimensions of $400 \mathrm{x} 500 \mathrm{~mm}$ which have a clamping force of 1,587.08 kN. Examples of machines that can be used are JSW J180AD injection machines with a maximum clamping force of $1770 \mathrm{kN}$.
\end{abstract}

Key Words: Mold Unit, Layout, Injection Molding, Runner System

\section{Introduction}

Nowadays, the proliferation of plastic products is inevitable given the malleable, lightweight, and inexpensive plastic material. The manufacturing process of a plastic material into a product involves several methods. One of such methods is the plastic injection method by forming components or products using plastic ore as raw material heated at a certain temperature until it melts and then injected into a mold (Djunarso, 2011).

In the plastic injection process, several factors are known to determine the result of a product, one of the most important of which is the mold design. In designing the mold unit, we need to consider the dimensions to be used because this will affect the costs in the mold making process as well as the clamping force required to hold the mold during the injection process.

One of the widely used products by the community is plastic-based spoons and forks. Plastic-based spoons and forks commonly are produced by way of the plastic injection method. These products are frequently used in everyday life, because of the large availability and affordability of plastics. Given the usability of spoons and forks, innovations are made by combining plastic-based spoons and forks into one, an innovation widely known as spork. This innovation benefits many travellers, campers, or those in other mobile conditions due to its efficiency. Plastic-based products are normally produced massively with a low selling price, therefore choosing a mold unit design is very important to reduce operational costs while still producing good quality products in large quantities.

In this study, researchers will design a mold unit for a combined spork that is yet to gain its popularity in the community. This study focuses on the following aspects: the design of the grid layout mold unit, the radial layout mold unit design, the measurement of the clamping force, and the determination of injection machine that can be used for mold design.

\section{Metodhology}

To determine the optimum mold unit design from the grid layout and radial layout, the mold unit design is adjusted to the LKM moldbase standard. The first standard is LKM AI 4050 and the second is LKM AI 6050. The layout of the grid type runner system can be seen in Figure 2-1, and the Radial type in 
Figure 2-2. For model design, this study used injection simulation and molding design from
Autodesk software, namely Inventor and Moldflow.

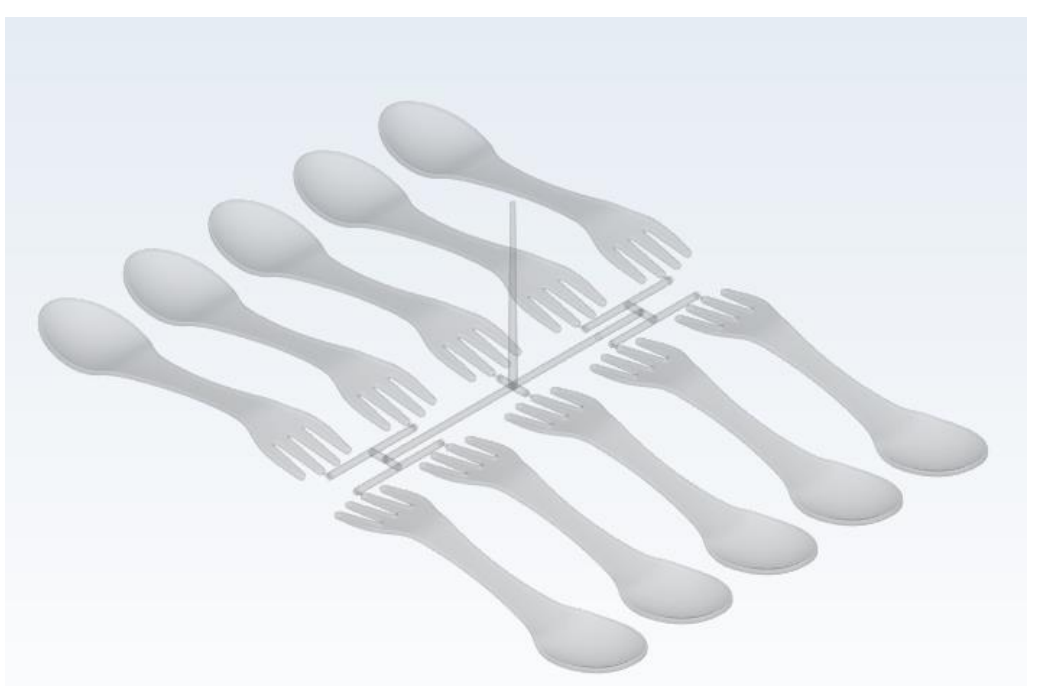

Figure 2-1. Grid Layout

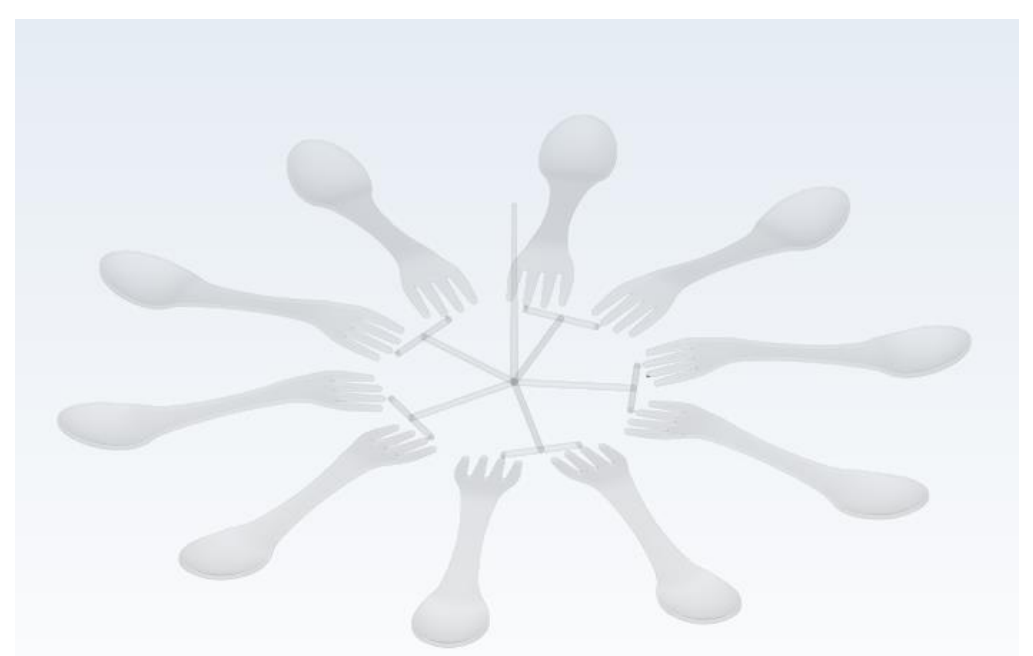

Figure 2-2. Radial Layout 


\section{Results and Discussion}

\subsection{Mold Unit Design}

This study will design the following two types of layout into a mold unit: a grid layout with core and cavity dimensions of 232 x $359 \mathrm{~mm}$ and a radial layout with core and cavity dimension of $430 \times 439 \mathrm{~mm}$.

\subsubsection{Moldbase grid layout}

\section{Moldbase}

The design of combined spork used the LKM AI 4050 moldbase standard shown in Figure 3-1 as the grid layout. The basis for determining the plate material and mold components refers to the basic mold design textbook with direct reference from LKM standards as a manufacturer of moldbase components.

\section{Top Clamping Plate}

Top Clamping Plate is the main plate that serves to tie the entire plastic injection molding system. The clamping top is located on the top (stationary plate and movable plate). This top clamping uses S55C material which is made of carbon steel. Figure 3-2 shows top clamping modelling.

\section{Cavity plate}

Cavity plate is used to hold the cavity. The cavity plate image is shown in Figure 3-3.

\section{Core plate}

Core plate is used to hold the core. The core plate image is shown in Figure 3-4.

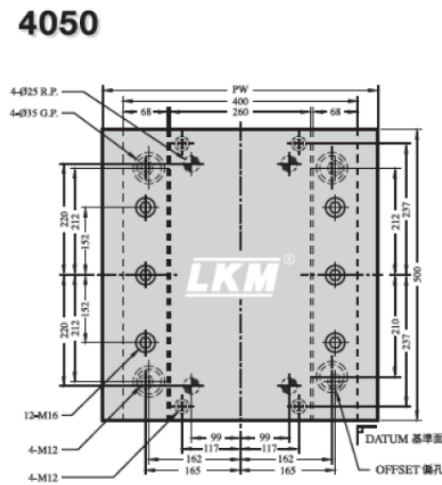

Figure 3-1. Moldbase Standard LKM AI 4050 .

(Source: LKM, 2015)

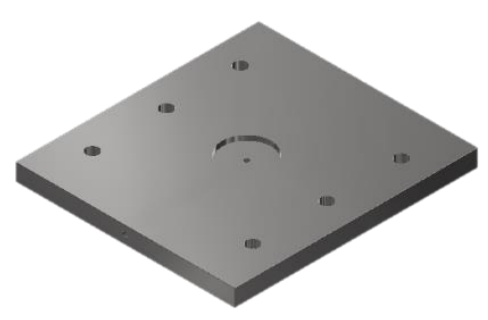

Figure 3-2. Top Clamping Plate.

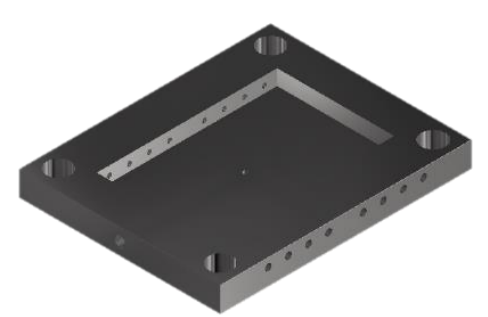

Figure 3-3. Cavity Plate.

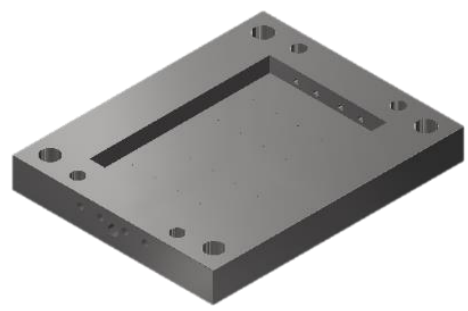

Figure 3-4. Core Plate. 


\section{Cavity}

Cavity is one part of the injection mold that serves for forming a product. The cavity image is shown in Figure 3-5.

\section{Core}

Core is one part of the injection mold for forming a product. The core image is shown in Figure 3-6.

\section{Support plate}

The support plate supports or helps the core plate to avoid changing shape. The location of the support plate is under the core plate. The width and height of this plate is exactly the same as the plate above it, with only difference in the thickness. Figure 3-7 shows the modeling of the support plate.

\section{Spacer Block}

The spacer block provides a gap between the support plate and the clamping plate so that it allows the ejector system to move back and forth to remove the product. Figure 3-8 shows the modeling of the right and left spacer blocks.

\section{Ejector System}

The ejector system is divided into two: the ejector plate and the ejector retainer which function to bind the ejector pin and return pin. The ejector system also functions to remove the product in the mold. Figure 3-9 shows the modeling of the ejector system.

\section{Bottom clamping plate}

This plate is placed at the bottom with a larger and wider size than the core plate. It functions to tie the mold with a machine movable plate. Figure 3-10 shows modeling of a bottom clamping plate.

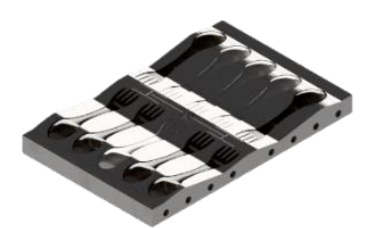

Figure 3-5. Cavity.

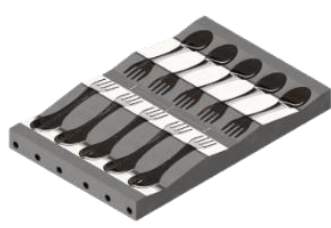

Figure 3-6. Core.

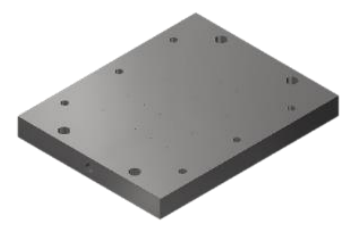

Figure 3-7. Support Plate
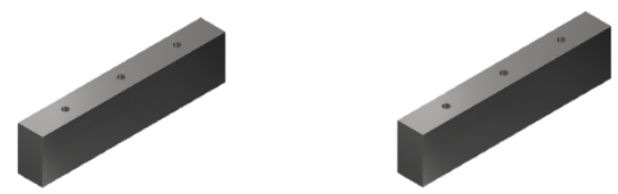

Figure 3-8. Spacer Block.
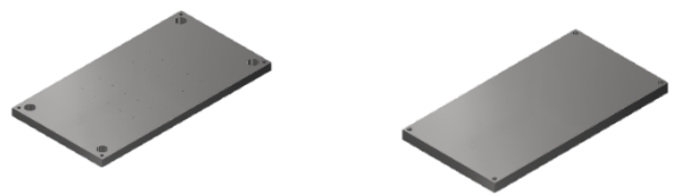

Figure 3-9. Ejector System.

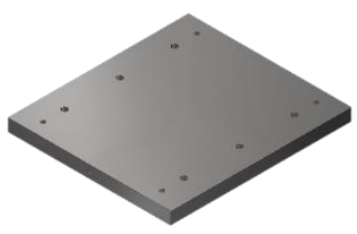

Figure 3-10. Bottom Clamping Plate 


\subsubsection{Moldbase layout radial}

\section{Moldbase}

In the radial layout of the spork produk, we used the LKM AI 6065 moldbase standard as shown in Figure 3-11. The basis for determining the plate material and mold components refers to the basic mold design textbook with direct reference from LKM standards as a manufacturer of mold components.

\section{Top clamping plate}

Top clamping plate is the main plate that serves to tie the entire plastic injection molding system. The top clamping plate is located on the top (stationary plate and movable plate). This top clamping uses S55C material which is made of carbon steel.

\section{Cavity plate}

This plate is used to hold the cavity. The cavity plate image is shown in Figure 3-13.

\section{Core plate}

This plate is used to hold core. The core plate figure is shown in Figure 3-14.

\section{Cavity}

Cavity is one part of the injection mold that molds a product. The cavity figure is shown in Figure 3-15.

\section{5}

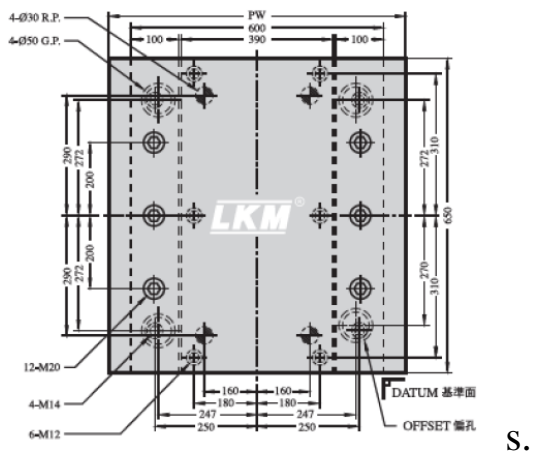

Figure 3-11. Moldbase Standard LKM AI 6065.

(Source: LKM, 2015)

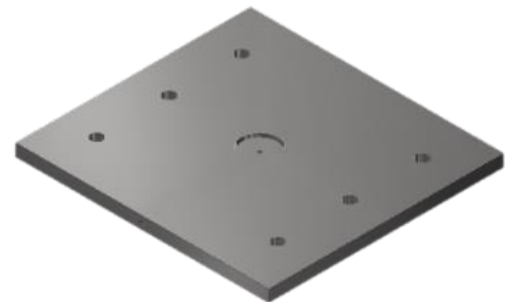

Figure 3-12 Top Clamping Plate.

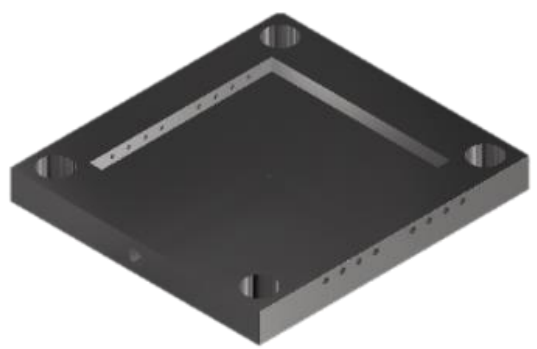

Figure 3-13. Cavity Plate.

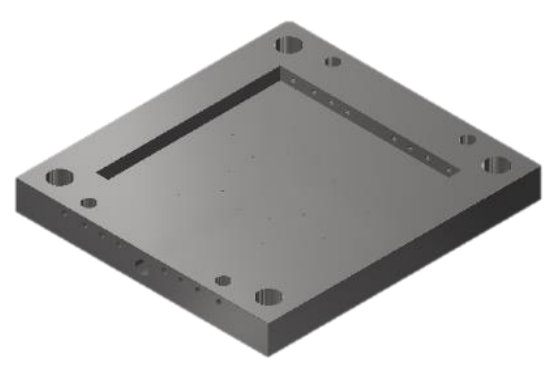

Figure 3-14. Core Plate.

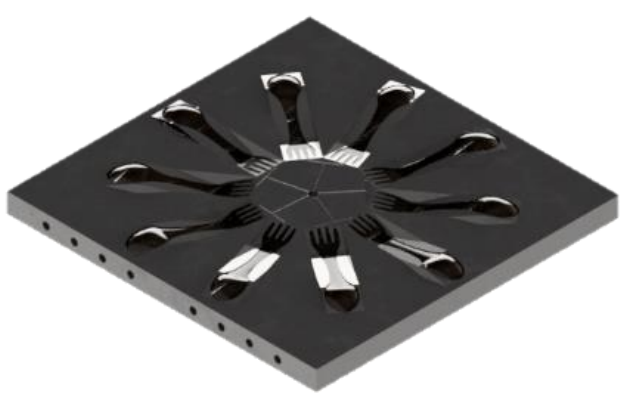

Figure 3-15 Cavity. 


\section{Core}

The core is one part of the injection mold that molds a product. The core figure is shown in Figure 3-16.

\section{Support plate}

The support plate serves to support or help the core plate so that it does not change shape. The location of the support plate is under the core plate. the width and height of this plate is exactly the same as the plate above it, only the thickness is different. Figure 3-17 shows the modeling of the support plate.

\section{Spacer block}

The spacer block serves to provide a gap between the support plate and the clamping plate, allowing the ejector system to move back and forth to remove the product. Figure 3-18 shows the modeling of the right and left spacer blocks.

\section{Ejector System}

The ejector system is divided into two: the ejector plate and the ejector retainer which function to bind the ejector pin and return pin. The ejector system also functions to remove the product in the mold. Figure 3-19 shows the modeling of the ejector system.

\section{Bottom Clamping Plate}

This plate is at placed the bottom, having a larger and wider size than the core plate. The function of the bottom clamping plate is to tie the mold with a machine movable plate. Figure 3-20 shows modeling of a bottom clamping plate.

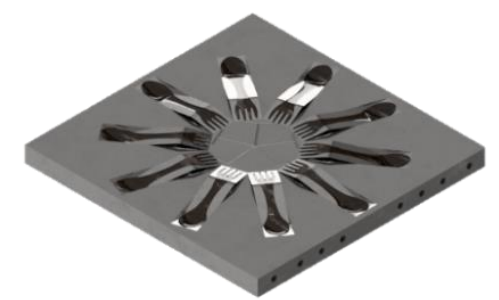

Figure 3-16. Core

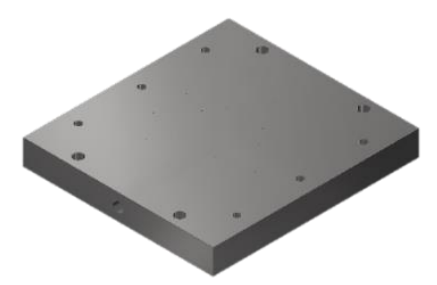

Figure 3-17. Support Plate.
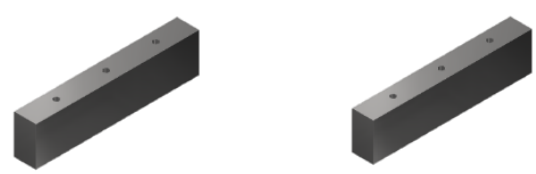

Figure 3-18. Spacer Block.
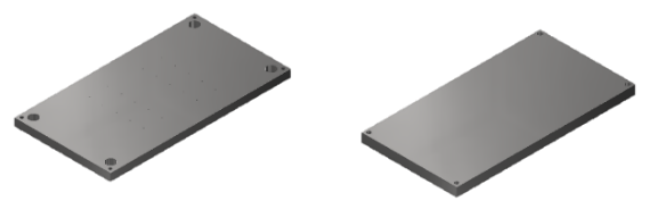

Figure 3-19. Ejector System.

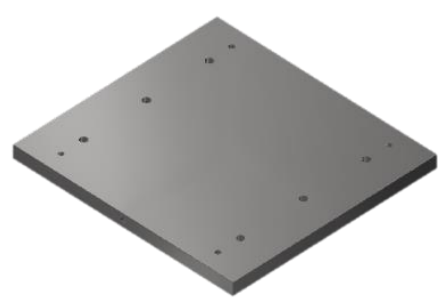

Figure 3-20. Bottom Clamping Plate. 


\subsection{Mold Unit Design Results}

Then the mold parts are put together or assembled according to the predetermined location, following the mold construction that has been assembled with 3D Figure as shown in Figure 3-21 and Figure 3-22 below.

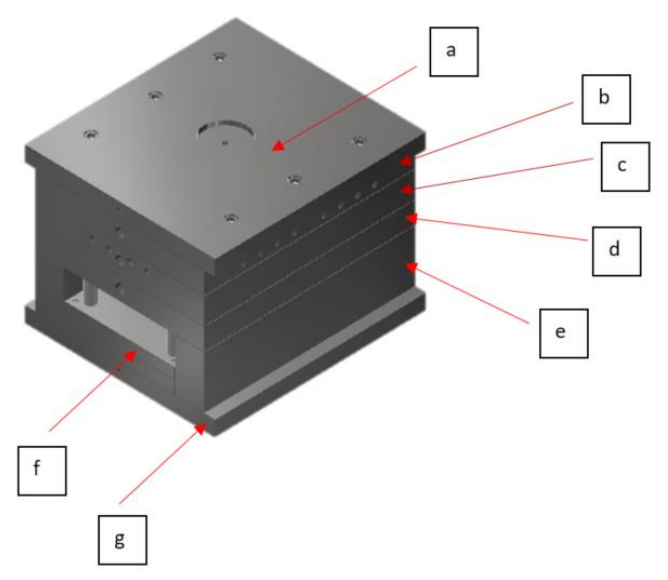
a. Top Clamping Plate
b. Cavity Plate.
c. Core Plate
d. Support Plate.
e. Spacer Block
f. Ejector System
g. Bottom Clamping Plate

Figure 3-21. The results of the mold layout grid design.

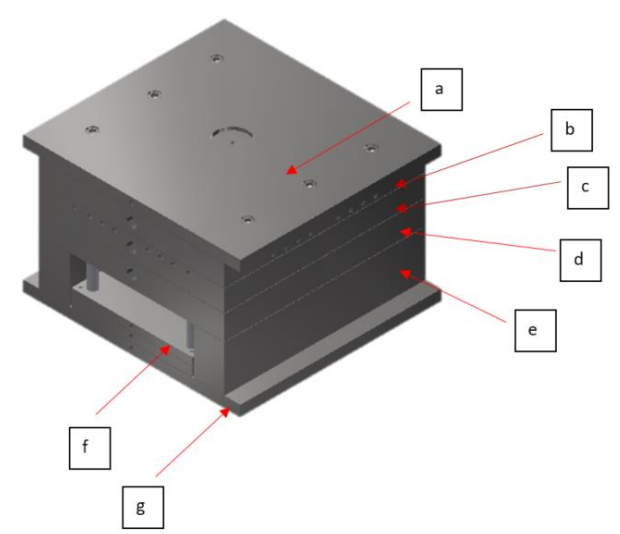

( The descriptions for each component are the same as in Figure 3-21 above)

Figure 3-22. Radial mold layout design results
Of the two mold unit designs, the grid layout mold dimensions are $400 \times 500 \mathrm{~mm}$, while the radial layout dimensions are $600 \mathrm{x}$ $650 \mathrm{~mm}$. The selection of these dimensions is highly influential on the manufacturing process and the operational costs for making the mold unit. Therefore, the most optimal dimension is a grid layout that uses a runner system block with smaller dimensions.

\subsection{The calculation results}

\subsubsection{Clamping Force Calculation}

The clamping force calculation aims to determine the force required by the machine to hold the two parts of the mold from opening during the injection process. Injection pressure and projection cross-sectional area are shown in Figure 3-23. The actual filling time, actual injection pressure, and clamping force area values were obtained from the simulation results using Autodesk MoldFlow Software. The actual filling time, actual injection pressure, and clamping force area values were obtained from the simulation results using the CAE MoldFlow Software.

\begin{tabular}{|c|c|}
\hline Actua flling time & $1.70(\mathrm{~s})$ \\
\hline Actud injection pressure & $50.810(\mathrm{MPa})$ \\
\hline Clampioce alea & $3123565(\mathrm{~cm} / 2)$ \\
\hline
\end{tabular}

Figure 3-23. Actual injection pressure and clamp force area

$\mathrm{Fc} \quad=\mathrm{P}_{(\text {inj })} \times \mathrm{A}$

It is known that:

$\mathrm{P}_{\text {(inj) }}=50,810 \mathrm{MPa}$

A $\quad=312,3565 \mathrm{~cm}^{2}$

Clamping Force can be calculated by the following:

$\mathrm{Fc} \quad=\mathrm{P}_{(\mathrm{inj})} \times \mathrm{A}$

$=5081 \mathrm{~N} / \mathrm{cm}^{2} \times 312.3565 \mathrm{~cm}^{2}$

$=1.587 .083,37 \mathrm{~N}$

$=1.587,08 \mathrm{kN}$

This calculation aims to determine the suitable injection machine used for the mold unit that has been designed. The result of the clamping force calculation required by the 
combined product mold for the spoon and fork is $1,587.08 \mathrm{kN}$.

\subsection{Example of Machine Selection}

The selected machine must have a clamping force that exceeds the required clamp force of $1587.08 \mathrm{kN}$. An example of an injection machine that can be used is the JSW J180AD injection machine with a maximum clamping force of $1770 \mathrm{kN}$. Hence, the mold that is designed must have a clamping force below $1770 \mathrm{kN}$ in accordance with the strength of the existing injection molding machine. For setting, when the injection process is still used, the related pressure according to the calculation is $1587.08 \mathrm{kN}$.

\section{Conclusion}

The conclusions from the research on "Injection Molding Unit Design of a of a Spork Product" are as follows:

1. Mold Unit with grid layout obtained the best result because it has smaller dimensions of $400 \times 500 \mathrm{~mm}$.

2. The clamping force required by the combined product mold for the spoon and fork is $1,587.08 \mathrm{kN}$.

3. One of the injection machines that can be used for the unit mold design is the JWS J180AD injection machine with a maximum clamping force of 1770 $\mathrm{kN}$.

\section{References}

Bayer Material Science. (2000). Part and Design. Retrieved from https://www.bayer.com on 10/5/2019.

Bob Hatch. (2003). Sizing Runner. Retrieved from https://www.plasticstoday.com on $14 / 5 / 2019$.

Cahyadi, D. (2014). Analisis Parameter Operasi pada Proses Plastik Injection Molding untuk Pengendalian Cacat Produk. JURNAL MESIN TEKNOLOGI, Vol. 8, No. 2.

Darmawan, Jarot \& Bambang Waluyo Febriantoko. (2018) Pengaruh Variasi Suhu Terhadap Cacat Short Shot Pada Produk Injection Molding Berbahan
Polypropylene (PP). Skripsi thesis, Universitas Muhammadiyah Surakarta. Djunarso. (2011). Dasar Mold Desain. Surakarta.

Hakim, A. R. (2016). Pengaruh Suhu, Tekanan dan Waktu Pendinginan Terhadap Cacat Warpage Produk Berbahan Plastik. Jurnal Dimensi, Vol. 5, No. 1.

Hedy Yeh. (2014). Injection Mold Cavity. Retrieved from www.plasticsmold.com on 20/5/2019

Yulianto, Irwan (2014). Rancangan Desain Mold Knob Regulator Kompor Gas Pada Proses Injeksi Molding. Reka Integra, Vol. 2, No. 3, 140-151.

LKM. (2015). Side Gate System Mold Base. Republic of China: Heyuan Lung Kee Metal Products Co., Ltd.

Mike Hudspeth. (2016). Plastic Parts Design 101. Retrieved from www.engineersrule.com pada 20/5/2019.

Mujiarto, I. (2005). Sifat dan karakteristik material plastik dan bahan aditif. Jurnal Traksi, 3(2), 11-17.

Nanoplas, Inc. (2014). Cold Runner vs Hot Runner Molding System. Retrieved fro https://www.nanomoldcoating.com on 25/5/2019.

Shoemaker, J. (2006). Moldflow design guide: a resource for plastics engineers (Vol. 10). Hanser Verlag.

Sinotech. (2017). Injection Molding. Retrieved from https://www.sinotech.com

Wahjudi, D., San, G. S., \& Pramono, Y. (2004). Optimasi proses injeksi dengan metode Taguchi. Jurnal Teknik Mesin, Vol. 3, No. 1, 24-28. 